\title{
Developmental and Growth Factor-Induced Regulation of Nestin in Oligodendrocyte Lineage Cells
}

\author{
Vittorio Gallo' and Regina C. Armstrong² \\ 1 Laboratory of Cellular and Molecular Neurophysiology, NICHD, NIH, Bethesda, Maryland 20892, and ${ }^{2}$ Department of \\ Anatomy and Cell Biology, Uniformed Services University of the Health Sciences, Bethesda, Maryland 20814
}

\begin{abstract}
The expression and regulation of nestin, an intermediate filament protein associated with neuroepithelium-derived progenitor cells, was studied in developing oligodendrocytes. We analyzed glial cells cultured from late embryonic rat cerebral cortex, tissue prints from neonatal rat brains, and the oligodendrocyte cell line CG-4. Using cortical- or CG-4-derived oligodendrocyte lineage cells, Northern blot analysis demonstrated that nestin mRNA was highly expressed in proliferating 0-2A progenitors, but downregulated in differentiated oligodendrocytes. Immunocytochemistry of cultured cells and tissue prints demonstrated that pre-O2A cells and 0-2A progenitors expressed high levels of the nestin protein. In contrast, nestin expression decreased during the pro-oligodendroblast stage, and the majority of oligodendrocytes were not labeled with anti-nestin antibodies. Culture conditions (PDGF + bFGF or B104-conditioned medium) that maintained $0-2 \mathrm{~A}$ progenitor proliferation and prevented differentiation enhanced expression of nestin mRNA transcripts and protein. In comparison, analysis of cortical astrocyte cultures demonstrated that type 1 astrocytes, but not type 2, expressed nestin mRNA and protein. Our findings demonstrate that nestin is expressed in developing glial cells, which is suggestive that this intermediate filament protein may play an important role during gliogenesis.
\end{abstract}

IKey words: O-2A progenitors, intermediate filaments, CG-4 cells, platelet-derived growth factor, basic fibroblast growth factor, B104 neuroblastoma]

Each of the major neuronal and macroglial cell types in the CNS is derived from neuroepithelial cells of the primitive neural tube (Sauer, 1935). Single neuroepithelial cells can give rise to mixed

Received Mar. 7, 1994; revised June 1, 1994; accepted June 23, 1994.

We thank Ron McKay and George Vaughn for generously supplying the antinestin antibodies and the nestin cDNA, and for helpful discussions. We thank Jean-Claude I ouis for providing the CG-4 cell line and Iynne Holtzclaw for astrocyte cultures. We are grateful to Monique Dubois-Dalcq and Giulio Levi for their generous gift of O4, O1, LB1, and RmAb antibodies. We thank Paul Wright, Tamara Donan, and Courtney Bradley for technical help, and Rosemary Borke and Kristen Blake for assistance with the animal perfusion. We thank Ron McKay, Montse Molne, Mario Pende, Steve Scherer, and Paul Wright for their valuable comments on the manuscript. This work was supported in part by Uniformed Services University of the Health Sciences Grant R070CB. The opinions expressed are our private views and should not be construed as official or necessarily reflecting the views of the Uniformed Services School of Medicine or the Department of Defense.

Correspondence should be addressed to Dr. Vittorio Gallo, Laboratory of Cellular and Molecular Neurophysiology, NICHD, NIH, Building 49, Room 5A78, Bethesda, MD 20892.

Copyright (C) 1995 Society for Neuroscience $0270-6474 / 95 / 150394-13 \$ 05.00 / 0$ clones of neurons, astrocytes, and/or oligodendrocytes (Price and Thurlow, 1988; Vaysse and Goldman, 1990; Williams et al., 1991; Halliday and Cepko, 1992; Levison and Goldman, 1993). In the developing CNS, neuroepithelial precursor cells can be identified by the presence of nestin, an intermediate filament protein highly expressed during neurogenesis and subscquently attenuated in mature ncurons (Hockficld and McKay, 1985; Frederiksen et al., 1988; Lendhal et al., 1990). However, expression of nestin in neuroepithelial cells during gliogenesis has not been analyzed. Among the different glial cell types, oligodendrocytes are generated during early postnatal development, well after the formation of the neuronal components of the brain and spinal cord, and are thus among the last cell types to arise (LeVine and Goldman, 1988; McCarthy and Leblond, 1988; Reynolds and Wilkin, 1988). Therefore, nestin expression in oligodendrocyte lineage cells could suggest a common precursor for oligodendrocytes and neurons, and/or a common role for nestin during the development of each cell type.

Analyses of CNS precursor cells have been facilitated by procedures to isolate specific cell populations from embryonic tissues and manipulate cells in controlled culture conditions (Gensburger et al., 1987; Frederiksen et al., 1988; Temple, 1989; Reynolds and Weiss, 1992; Stemple and Anderson, 1992; Kilpatrick and Bartlett, 1993). Embryonic CNS precursor cells express nestin (Frederiksen and McKay, 1988; Reynolds et al., 1992) and can be expanded by mitogens that act sequentially to generate neurons and glial cells (Deloulme et al., 1991; Stemple and Anderson, 1992; Vescovi et al., 1993). Similarly, cell cultures derived from postnatal CNS have been used to analyze oligodendrocytc devclopment (revicwed in Dubois-Dalcq and Armstrong, 1992). Oligodendrocytes are derived from precursor cells of the germinal matrix zone that migrate to formative white matter regions, differentiate, and then form myelin sheaths. Oligodendrocyte maturation progresses through distinct stages that have been defined by the expression of developmentally regulated antigens. Oligodendrocyte progenitors (O-2A) express GD3 ganglioside, recognized by $\mathrm{LB1}$, as well as other gangliosides recognized by A2B5 monoclonal antibody (Raff et al., 1983; Goldman et al., 1984; Levi et al., 1986). In vitro, O-2A progenitors can be expanded clonally by growth in platelet-derived growth factor (PDGF) and basic fibroblast growth factor (bFGF) (Raff et al., 1988; Bogler et al., 1990; McKinnon et al., 1990; Gard and Pfeiffer, 1993). Late progenitors, or pro-oligodendroblasts, can be recognized by the $\mathrm{O} 4$ monoclonal antibody (Sommer and Schachner, 1981; Dubois-Dalcq, 1987; Gard and Pfeiffer, 1990; Warrington and Pfeiffer, 1992). Mature oligodendrocytes continue to express antigens recognized by $\mathrm{O} 4$, while 
acquiring galactocerebroside immunoreactivity (Raff et al., 1978; Bansal et al., 1989). Finally, mature oligodendrocytes go on to synthesize additional specific components required for myelin formation (Zeller et al., 1985).

Determining the pattern of nestin expression and its regulation during development can provide important insights into mechanisms of precursor cell proliferation and lineage commitment. Therefore, we studied nestin mRNA and protein expression in oligodendrocyte lineage cells to correlate nestin regulation with spccific dcvclopmental stages. We also determined the effect of mitogenic growth factors on the abundance of nestin mRNA transcripts. We extended our analysis to an oligodendrocyte cell line, CG-4, that displays developmental and functional characteristics of cortical O-2A progenitors (Louis et al., 1992a; Patneau et al., 1994; Pende et al., 1994).

\section{Materials and Methods}

Cell cultures. Purified cortical O-2A progenitor cultures were prepared by modifications of previously described methods (Armstrong et al. 1990b; McKinnon et al., 1990). Briefly, E20-P1 Sprague-Dawley rats wcrc killcd by decapitation and their cortices were removed, mechanically dissociated, suspended in Dulbecco's Modified Eagle's Medium (DMEM; GIBCO-Bethesda Research Labs, Gaithersburg, MD) containing 10\% fetal bovine serum (FBS; Hyclone, Logan, UT), and plated in plastic T75 flasks. After $12 \mathrm{~d}$ in culture, O-2A progenitor cells growing on top of a confluent monolayer of astrocytes were detached by overnight shaking (McCarthy and de Vellis, 1980). Contaminating microglial cells were further eliminated by plating this fraction on plastic culture dishes for $1 \mathrm{hr}$. The O-2A progenitor cells, which do not attach well to plastic, were collected by gently washing the dishes, replated $\left(18-25 \times 10^{3}\right.$ cells/ $\mathrm{cm}^{2}$ ) onto poly-D-ornithine-coated plates $(0.1 \mathrm{mg} / \mathrm{ml})$, and cultured in DME-N1 biotin-containing medium supplemented with $30 \%$ B104conditioned medium (B104-CM) for 1-3 d prior to immunocytochemical staining or harvesting for RNA preparations. Differentiation into oligodendrocytes was promoted by withdrawing the B104-CM and growing the O-2A progenitors for an additional 3-5 d in DME-N1 medium with $2 \%$ FBS. Cortical O-2A progenitors treated with growth factors were cultured up to $3 \mathrm{~d}$ and treated every $24 \mathrm{hr}$ with bFGF (10 $\mathrm{ng} / \mathrm{ml}$ ) and PDGF $(10 \mathrm{ng} / \mathrm{ml}$ ) (both from Upstate Biotechnology, Inc. Lake Placid, NY).

CG-4 cells were cultured as previously described by Louis et al. (1992a). Briefly, CG-4 progenitor cells were grown on poly-D-ornithine-coated dishes in DME-N1 biotin-containing medium supplemented with $30 \%$ B104-conditioned medium. CG-4 cells were passaged (1:3) every 3-4 d. CG-4 cultures enriched in oligodendrocytes or in type 2 astrocytes were obtained from cells grown for 5-8 d in DME-N1 containing $2 \%$ or $20 \%$ FBS, respectively (Louis et al., 1992a). Cortical astrocyte cultures were prepared as previously described (McCarthy and de Vellis, 1980). Bricfly, tissuc was dissociated with trypsin in the presence of DNase and cells were cultured in DMEM containing 10\% FBS (GIBCO-Bethesda Research Labs), $2 \mathrm{~mm}$ glutamine, and $2.5 \mu \mathrm{g} / \mathrm{ml}$ amphotericin $B$ (Fungizone). Cells were plated in T75 flasks and maintained at $37^{\circ} \mathrm{C}$ in $5 \% \mathrm{CO}$. The culture medium was changed every $3 \mathrm{~d}$. Cultures were then shaken overnight to eliminate the majority of oligodendrocyte lineage cells and microglia. Cells were reseeded on to coverslips and used for immunocytochemistry or replated in T75 flasks and harvested for RNA preparations after $14 \mathrm{~d}$ in culture. Cultures enriched in different cell types were characterized immunocytochemically by using cell-specific markers (see below). Both in CG-4 and cortical cultures enriched in O-2A progenitors, $90-95 \%$ of the cells were $\mathrm{LB1}{ }^{+}$(Patneau et al., 1994). In oligodendrocyte-enriched cultures, more than $85 \%$ of the cells were $\mathrm{Ol}^{+}$and the remaining cells were ${ }^{+}{ }^{+}$(Patneau et al., 1994). Cell cultures used for immunostaining were grown on glass coverslips precoated with poly-D-ornithine.

$R N A$ isolation and Northern blot analysis. Total RNA was isolated from CG-4 cells using the guanidine thiocyanate procedure (Chirgwin et al., 1979). Total RNA was isolated from cortical O-2A progenitors, oligodendrocytes, and type 1 astrocytes using a single-step procedure (RNAzol B; Tel-test, Friendswood, TX) (Chomczynski and Sacchi, 1987). RNA samples ( $15 \mu \mathrm{g} /$ lane) were separated by electrophoresis through a
$1.5 \%$ agarose-formaldehyde denaturing gel, electrotransferrcd onto Nytran (Schleicher and Schuell, Keene, NH) membranes, cross-linked to the membranes by UV irradiation (Stratalinker, Stratagene, CA), and hybridized with cDNA probes. The following cDNAs were used for random priming with $\alpha-{ }^{32} \mathrm{P}-\mathrm{dCTP}$ : AvaI internal fragment for nestin $(2.2 \mathrm{~kb}) ;$ pT7 $18 \mathrm{~s}$ ribosomal RNA template linearized with Hind III (Ambion, Austin, TX). Each probe was labeled at approximately $10^{\circ}$ $\mathrm{cpm} / \mu \mathrm{g}$ DNA. Blots were hybridized in $50 \%$ formamide at $42^{\circ} \mathrm{C}$, washed at high stringency with $0.1 \times \mathrm{SSC}$ at $60^{\circ} \mathrm{C}$, and exposed to film for $3-4$ d. Nestin and $18 \mathrm{~s}$ transcripts were quantified using a phosphorimager system (Molecular Dynamics, Sunnyvale, CA).

Immunocytochemistry and counting of cell cultures. The following primary antibodies were used: LBI (Levi et al., 1986; Curtis et al., 1988); O4 (Sommer and Schachner, 1981); O1 (Sommer and Schachner, 1981); anti-nestin (Tohyama et al., 1992); anti-GFAP (Boehringer, Mannheim); and anti-Thy-1 (Chemicon Int., Temecula, CA). All secondary fluorochrome-conjugated antibodies were from Cappel-Organon Teknika (Durham, NC). Double indirect immunofluorescence experiments were performed as previously described (Gallo and Bertolotto, 1990). For staining with antibodies to cell surface components (LBI, O4, OI, and Thy-1), live cells were incubated for $30 \mathrm{~min}$ with primary antibodies diluted in DMEM, followed by fluorescein-conjugated goat anti-mouse (GAM) IgG (for LB1 and anti-Thy-1) or IgM (for O4 and O1) for 20 min. After extensive washing in DMEM, cells were fixed in $4 \%$ para-

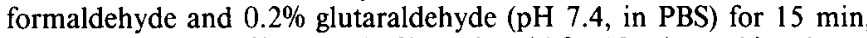
permeabilized in $95 \%$ ethanol $/ 5 \%$ acetic acid for $10 \mathrm{~min}$, and incubated with anti-nestin polyclonal rabbit antibody $(1: 1000$ in $1 \%$ FBS $+0.5 \%$ bovine serum albumin) overnight at $4^{\circ} \mathrm{C}$. After incubation with goat anti-rabbil (GAR) rhodamine-conjugated IgG + IgM for $30 \mathrm{~min}$, cells were mounted in Vectashield (Vector Laboratories, Burlingame, CA). For double staining with nestin and monoclonal anti-GFAP antibody, cells were fixed and permeabilized as described above, and then incubated with anti-GFAP antibody (1:4), followed by fluorescein-conjugated GAM IgG. After extensive washes in PBS and incubation with anti-nestin antibodies overnight at $4^{\circ} \mathrm{C}$, cells were incubated with GAR rhodamine-conjugated IgG + IgM, washed, and mounted in Vectashield. Controls for antibody specificity were performed by omitting the primary antibodies in the immunostaining protocols. The immunofiuorescence pictures presented are representative of at least three experiments. Both for CG-4 and cortical cultures, cell counts were obtained from three separate experiments. Three coverslips per experiment were analyzed and 5-10 fields per coverslip were counted ( $80-200$ cells $/$ field).

For BUdR staining, cells were pulsed with $50 \mu \mathrm{m}$ BUdR for $12 \mathrm{hr}$, fixed in $4 \%$ paraformaldehyde for $10 \mathrm{~min}$ at room temperature, and incubated with $0.07 \mathrm{~N} \mathrm{NaOH}$ for $10 \mathrm{~min}$ at room temperature. After washing in PBS, cells were fixed in $4 \%$ paraformaldehyde for $10 \mathrm{~min}$ and permeabilized in $0.2 \%$ Triton X-100 in PBS for $10 \mathrm{~min}$. After washing in PBS, cells were incubated with $10 \%$ heat-inactivated goat serum for $15 \mathrm{~min}$, with monoclonal anti-BUdR antibodies (1:20; Dako Corp., Carpinteria, CA) for $1 \mathrm{hr}$, and with fluorescein-conjugated GAM IgGr for $30 \mathrm{~min}$. Five coverslips (10 fields per coverslip) were counted from two separate experiments for each culture condition (control without growth factors, PDGF, bFGF, PDGF + bFGF, B104-CM).

Preparation of tissue prints. Acutely dissociated "touch preparations" of fresh neonatal rodent cerebrum were prepared as described previously (Armstrong et al., 1992), with minor modifications in the enzymatic digestion protocol. Postnatal day 3 and day 5 Sprague-Dawley rats were decapitated and their brains were immediately removed, cut into thin coronal slices with a razor blade, and then digested at $37^{\circ} \mathrm{C}$ for $45 \mathrm{~min}$ in $30 \mathrm{U} / \mathrm{ml}$ papain (Worthington, Freehold, NJ) in MEM-HEPES with 0.2 mm EDTA (Sigma, St. Louis, MI) and $1 \mathrm{~mm}$ cysteine (Sigma). The digested tissue was then transferred to $0.2 \%$ ovomucoid (Worthington) in MEM-HEPES for $5 \mathrm{~min}$ at room temperature, and then to a solution of $0.2 \mathrm{M} \mathrm{CaCl}_{2}$ (Sigma). Tissue slices were printed to Cell-Tak (Biopolymers, Inc., Farmington, CT)-coated glass coverslips and immediately fixed with $2 \%$ paraformaldehyde for $12 \mathrm{~min}$, so that a monolayer of cells remained attached to the coverslips. The cells were then immunostained (see below).

Preparation of tissue sections. Postnatal day 3 and 7 Sprague-Dawley rats were anesthetized and perfused transcardially with $4 \%$ paraformaldehyde as described by Borke et al. (1993). Midcoronal slices of the brain and transverse slices of cervical spinal cord were immersed in $4 \%$ paraformaldehyde overnight at $4^{\circ} \mathrm{C}$, transferred to $0.5 \mathrm{M}$ sucrose for 24 $\mathrm{hr}$ at $4^{\circ} \mathrm{C}$, and then immersed in OCT embedding medium (Baxter Scientific Products, McGaw Park, IL) prior to freezing onto aluminum 


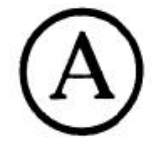

\section{CORTICAL GLIA}

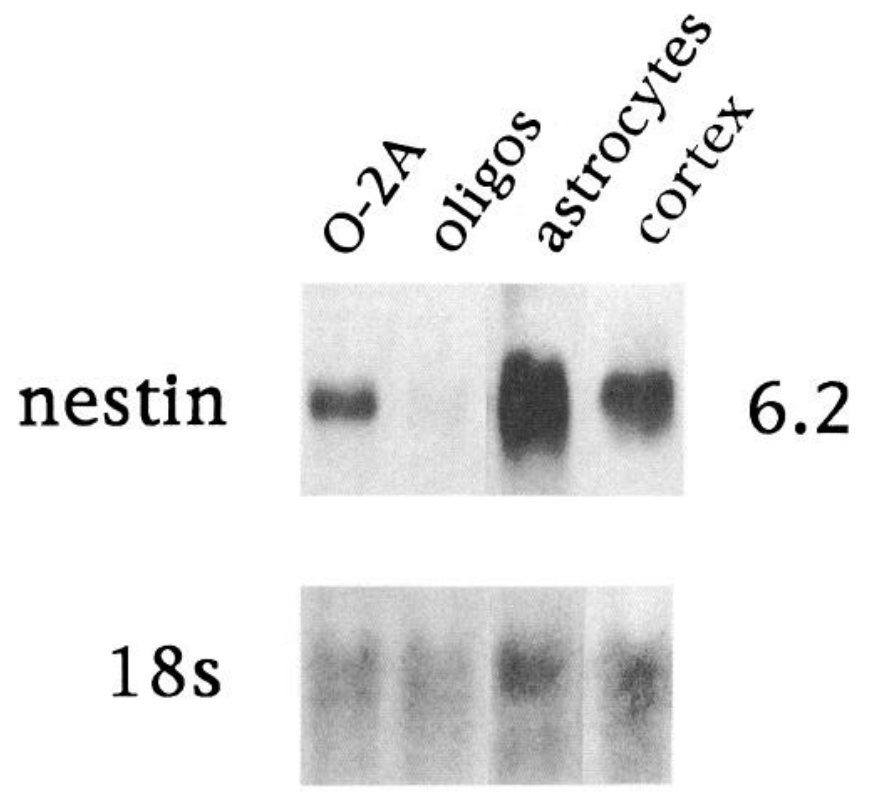

lane: $\quad \begin{array}{llll}1 & 2 & 3 & 4\end{array}$

\section{CG-4 CELLS}

nestin

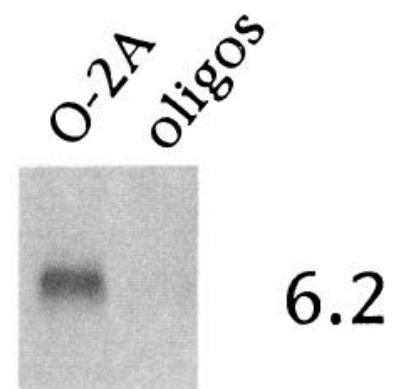

\section{$18 \mathrm{~s}$}

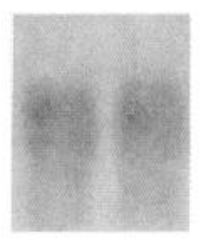

lane:

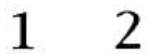

Figure 1. Expression and regulation of nestin mRNA in cells of the oligodendrocyte lineage and in astrocytes. $A$, Northern blot analyses of primary cortical glial cultures and rat cerebral cortex. Lane 1, O-2A progenitors cultured in 30\% B104-conditioned medium (CM) for $3 \mathrm{~d}$; lane 2, differentiated oligodendrocytes (oligos), $8 \mathrm{~d}$ in culture; lane 3, cortical astrocytes, $14 \mathrm{~d}$ in culture; lane 4 , postnatal day 1 cerebral cortex. $B$, Northern blot analyses in CG-4 cells. Lane 1, O-2A progenitors foil and storing at $-20^{\circ} \mathrm{C}$. Fifteen micron sections of tissue were cut on a Bright-Hacker cryostat and thaw-mounted onto gelatin-coated slides.

Immunocytochemistry of tissue prints and sections. Double and triple indirect immunofluorescence protocols were adapted from previously described methods (Armstrong et al., 1990a). All secondary fluorochromes were purchased from Jackson Immunoresearch (West Grove, PA). To immunostain cell surface antigens, fixed tissue-printed cells (see above) were incubated with primary mouse monoclonal IgM antibodies (A2B5, Eisenbarth et al., 1979; O4 or O1, Sommer and Schachner, 1981) followed by FITC- or AMCA-conjugated goat anti-mouse $\mathrm{IgM}$, and/or with Ranscht monoclonal IgG3 antibody ( $\mathrm{RmAb})$, followed by FITC-conjugated goat anti-mouse IgG3. RmAb recognizes galactocerebroside and an antigen that precedes galactocerebroside (Ranscht et al., 1982; Bansal and Pfeiffer, 1992). To immunostain intermediate filament proteins, the tissue-printed cells were first permeabilized in $95 \%$ ethanol: $5 \%$ acetic acid for $7 \mathrm{~min}$ at $-20^{\circ} \mathrm{C}$, washed three times with MEM containing 10\% FBS and three times with PBS, and then incubated with primary antibodies. Polyclonal rabbit antisera against nestin (Tohyama et al., 1992) or against GFAP were visualized with a Cy3-conjugated donkey anti-rabbit IgG antibody. Monoclonal antiGFAP mouse IgG1 antibody (Boehringer, Mannheim) and the monoclonal anti-nestin rat-401 IgG1 antibody (Hockfield and McKay, 1985) were visualized with either AMCA-conjugated goat anti-mouse IgG or FITC-conjugated donkey anti-mouse IgG. For each set of immunostains, triplicate tissue prints were examined from each of three independent sets of animals. To quantitate nestin expression in oligodendrocyte lineage cells, all of the $\mathrm{O}^{+}$cells were counted on coverslips from postnatal day 5 brains ( $2-4$ coverslips per brain from six animals; $n=441$ cells).

Tissue sections were immunostained with the same antibodies against nestin and GFAP, which were visualized using the same secondary antibodies listed above for tissue prints. Prior to immunostaining, sections were treated with a solution containing $25 \%$ normal rat sera (Jackson Immunoresearch), $0.4 \%$ Triton X-100 (Pierce, Rockford, IL), and $100 \mathrm{~mm}$ lysine (Sigma) in PBS.

\section{Results}

Nestin $m R N A$ expression and regulation in cells of the oligodendrocyte lineage

The expression and regulation of nestin mRNA in O-2A progenitors and oligodendrocytes was studied by Northern blot analysis. When total RNAs isolated from secondary cultures of purified cortical O-2A progenitors or from CG-4 cells were probed with a nestin cDNA fragment, a single $6.2 \mathrm{~kb}$ mRNA band was detected (Fig. $1 A, B$ ). The same $6.2 \mathrm{~kb}$ band previously described for nestin (Lendahl et al., 1990) was detected in neonatal rat cerebral cortex RNA (Fig. $1 A$ ). In cortical cultures, nestin mRNA levels were high in proliferating $\mathrm{O}-2 \mathrm{~A}$ progenitors, but extremely low in oligodendrocyte cultures (comprised of postmitotic cells, $85 \% \mathrm{O}^{+}$and $15 \% \mathrm{O}^{+} / \mathrm{Ol}^{+}$; Patneau et al., 1994) (Fig. 1A). A similar attenuation of nestin mRNA expression was observed in CG-4 cultures. CG-4 cells maintained at the O-2A stage by culturing in the presence of mitogenic factors (i.e., with B104-CM) expressed high levels of nestin mRNA, which declined in CG-4 cells cultured in the absence of mitogens (more than $85 \% \mathrm{Ol}^{+}$oligodendrocytes) (Fig. $1 B$ ).

cultured in $30 \%$ B104-CM for $3 \mathrm{~d}$; lane 2, differentiated oligodendrocytes (oligos), $8 \mathrm{~d}$ in culture. Total RNAs ( $15 \mu \mathrm{g}$ per lane) were hybridized with a $2.2 \mathrm{~kb}$ AvaI fragment obtained from the nestin cDNA. Nestin mRNA transcripts are highly expressed in dividing O-2A progenitors, but drastically downregulated in differentiated oligodendrocytes. Nestin mRNA transcripts are also abundantly expressed in astrocytes. The number on the right indicates the size of the nestin transcript in kilobases (derived from an RNA standard). The same blots were rehybridized with a cDNA probe for the 18s rRNA to control for uniform RNA loading. This was also demonstrated by ethidium bromide staining of the agarose gels prior to blotting (not shown). 

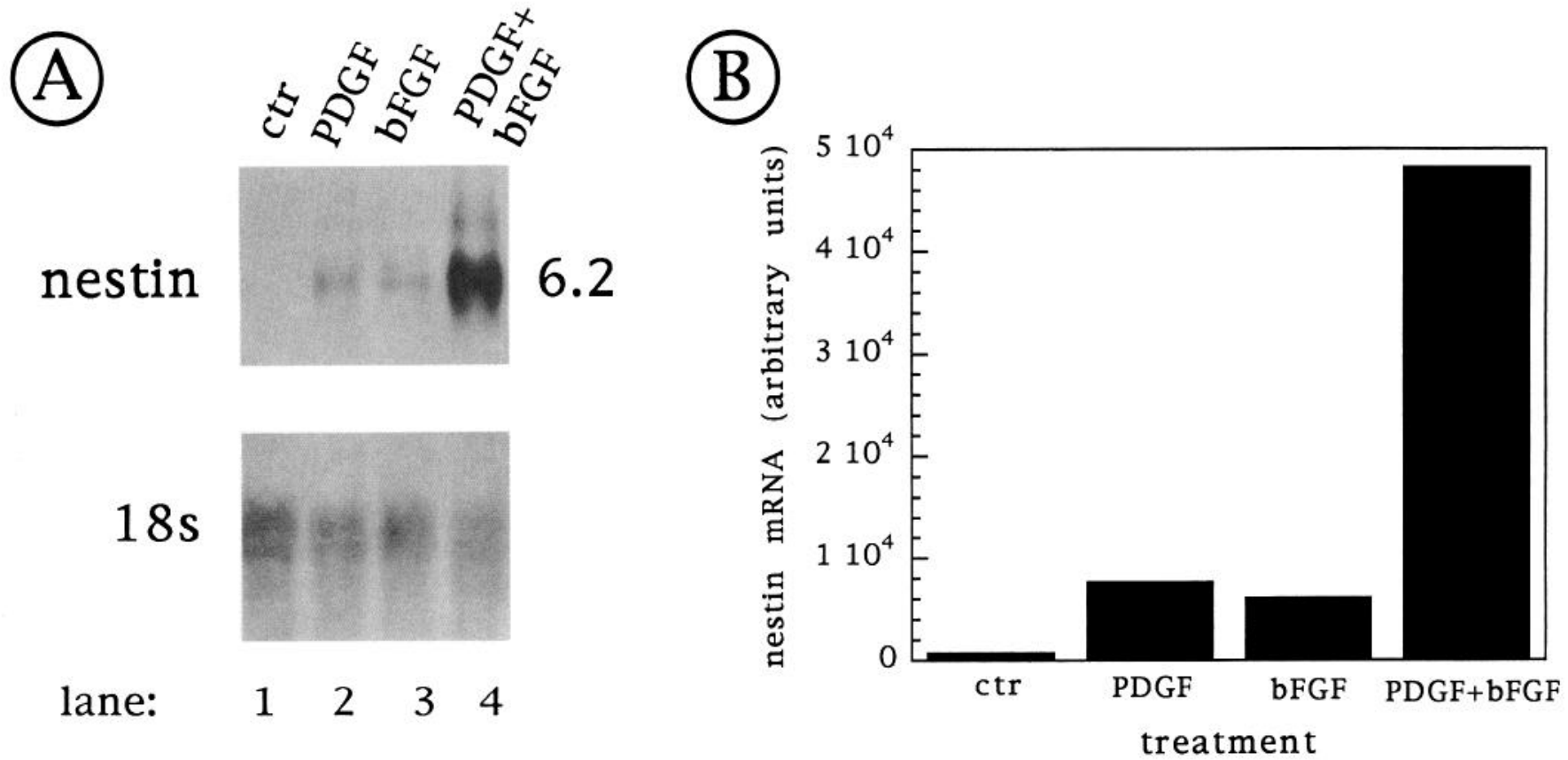

Figure 2. Nestin mRNA expression in O-2A progenitors is regulated by growth factors. A, Northern blot analyses of cortical O-2A progenitors cultured for $3 \mathrm{~d}$ in $\mathrm{N} 1+0.5 \%$ fetal bovine serum without growth factors (lane 1 ), or with $10 \mathrm{ng} / \mathrm{ml}$ PDGF (lane 2), $10 \mathrm{ng} / \mathrm{ml}$ bFGF (lane 3 ), or $10 \mathrm{ng} / \mathrm{ml}$ PDGF $+10 \mathrm{ng} / \mathrm{ml}$ bFGF (lane 4). Culture conditions that prevent O-2A progenitor differentiation (PDGF + bFGF) increase nestin mRNA. Visualization of $6.2 \mathrm{~kb}$ nestin mRNA transcripts and rRNA, as described in Figure 1 legend. $B$, Histogram obtained from phosphorimager quantitation of the Northern blot shown in $A$, normalized for the 18s rRNA. PDGF and bFGF independently (10-and 8-fold increase over control, respectively) and synergistically (63-fold increase over control, when combined in the culture medium) upregulate nestin mRNA.

When CG-4 cells were induced to differentiate to GFAP+ type 2 astrocytes, nestin transcript levels were also markedly decreased (data not shown). This downregulation appeared to correlate with the differentiation stage, rather than acquisition of GFAP specifically, since a single $6.2 \mathrm{~kb}$ nestin mRNA transcript was identified in rat cortical cultures comprised of approximately $85 \%$ GFAP $^{+}$type 1 astrocytes (Fig. $1 \mathrm{~A}$ ).

Since the nestin ${ }^{+} \mathrm{O}-2 \mathrm{~A}$ populations from cerebral cortex and from the CG-4 cell line were cultured in the presence of mitogens, we examined the ability of specific growth factors to regulate the expression of nestin mRNA. PDGF, bFGF, and B104$\mathrm{CM}$ are potent mitogens for O-2A progenitors (Bogler et al., 1990; McKinnon et al., 1990; Louis et al., 1992a). In our culture conditions, O-2A progenitors displayed distinctly different morphologies and proliferation rates, dependent upon which growth factor(s) was present in the culture medium, as previously described (Bogler et al., 1990; McKinnon et al., 1990; Louis et al., 1992a; Patneau et al., 1994). Cell proliferation assays performed with cortical $\mathrm{O}-2 \mathrm{~A}$ cells cultured in the presence of different growth factors for $3 \mathrm{~d}$ showed the following BUdR labeling indices (percent of total cells labeled with anti-BUdR antibody): $59.8 \pm 1.7$ in cells cultured with PDGF + bFGF; $66.6 \pm 3.9$ in B104-CM; $46.6 \pm 1.5$ in PDGF; $70.2 \pm 3.0$ in bFGF; and $16.4 \pm 1.7$ without mitogens. Figure 2 shows Northern blot analysis of total mRNA isolated from cortical O-2A progenitors cultured for $3 \mathrm{~d}$ with different mitogenic factors. Nestin mRNA levels were highest in cells treated with PDGF + bFGF (lane 4 ), but undetectable or very low in O-2A progenitors cultured without mitogens (lane 1). In cells cultured with PDGF or bFGF alone, nestin mRNA levels were significantly above detection (lanes 2 and 3), but much lower than those found with the combination of the two growth factors (Fig. 2A). When O-2A progenitors were exposed to both PDGF and bFGF for $3 \mathrm{~d}$, a more than 60 -fold increase was observed in nestin mRNA, compared to cells cultured in the absence of growth factors (Fig. $2 B)$. In the same experiment, a 23-fold increase was observed in nestin mRNA in O-2A cells cultured in B104-CM for $3 \mathrm{~d}$ (data not shown). The time course of the effects of PDGF + bFGF and of B104-CM on nestin mRNA expression showed that the effects of the mitogenic factors were evident after $1 \mathrm{~d}$ in culture (data not shown). These experiments demonstrate that nestin mRNA transcripts are abundant in proliferating $\mathrm{O}-2 \mathrm{~A}$ cell populations, as measured by BUdR labeling. Nestin mRNA levels are further increased by the synergistic action of PDGF and bFGF, as well as by factors contained in the B104-CM.

\section{Developmental regulation of nestin protein expression: immunocytochemical analysis}

We used double indirect immunocytochemistry to examine nestin protein expression at various stages of development within the oligodendrocyte lineage. Shortly after plating $(2 \mathrm{hr})$, a large proportion of cortical O-2A progenitors were clustered in groups of varying sizes. All cells contained in the clusters were stained with anti-nestin antibodies (Fig. 3A). However, the majority of these cells were not labeled with LB1 (Fig. $3 B$ ), a monoclonal antibody against the GD3 ganglioside, which is commonly used as an O-2A progenitor marker (Goldman et al., 1984, 1986; Levi et al., 1986; Curtis et al., 1988). These nestin+/LB1- cells were small and round, with little cytoplasm, a phenotype consistent with a pre-O-2A stage (Grinspan et al., 1990; Hardy and Reynolds, 1991). In separate experiments, cells of this morphology were labeled with an antibody against polysialylated N-CAM (R. C. Armstrong, unpublished observations), which identifies pre-O-2A cells (Trotter et al., 1989). A substantial 

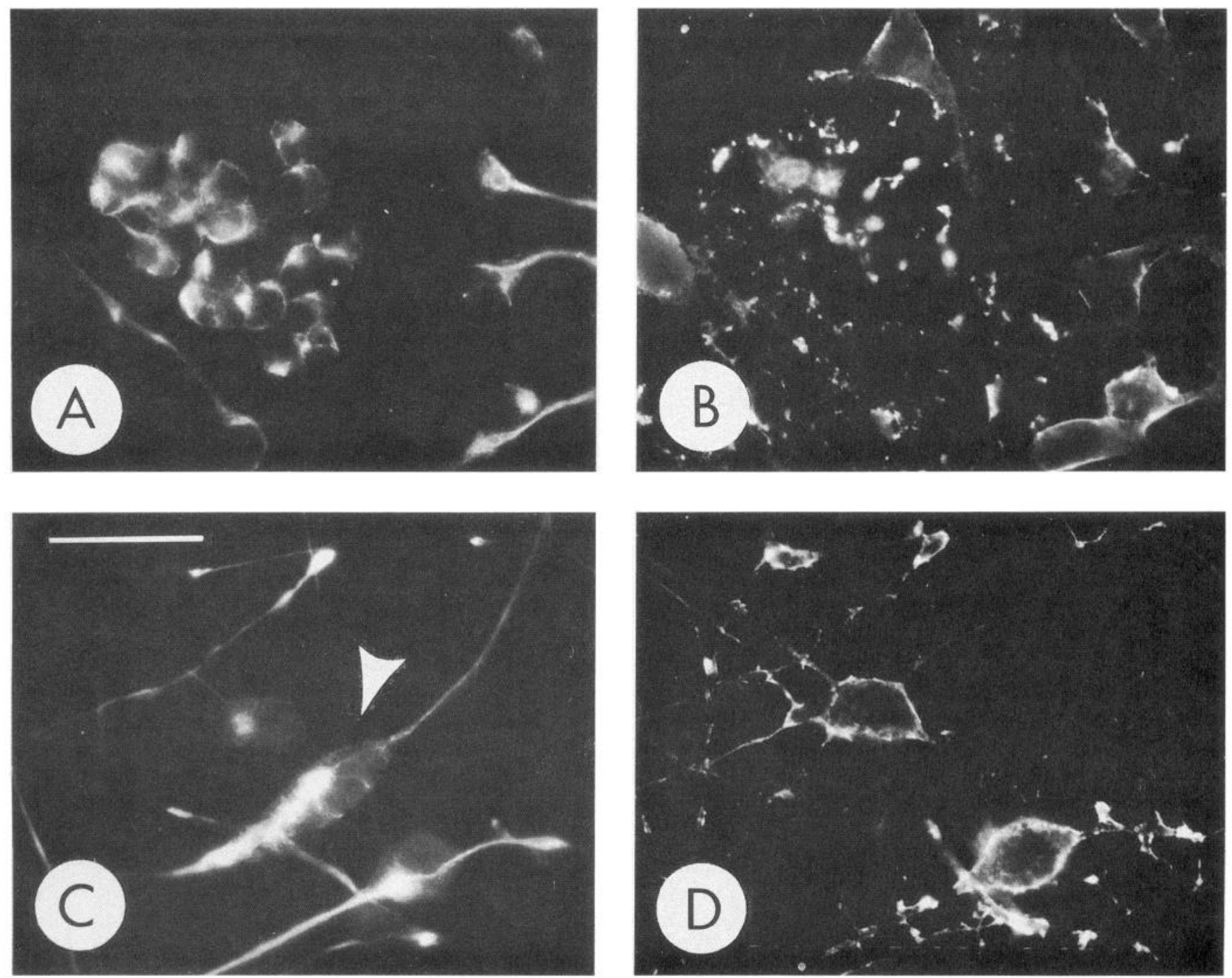

Figure 3. O-2A progenitors and pre-O-2A progenitors express nestin in vitro. Immunofluorescence staining of cortical O-2A progenitors cultured in $30 \% \mathrm{~B} 104-\mathrm{CM}$ for $2 \mathrm{hr}(A, B)$ or $3 \mathrm{~d}(C, D)$. Double staining with anti-nestin $(A, C)$ and $\mathrm{LB1}(B, D)$ antibodies. All the LB1 ${ }^{+} \mathrm{O}-2 \mathrm{~A}$ progenitor cells are nestin ${ }^{+}(A, C)$. Most of nestin ${ }^{+}$cells in the clusters are $\mathrm{LB1}^{-}$, whereas the vast majority of bipolar $\mathrm{O}-2 \mathrm{~A}$ progenitors migrating from the clusters are nestin ${ }^{+} / \mathrm{LB1}^{+}(B)$. After $3 \mathrm{~d}$ in culture, a significant percentage of nestin ${ }^{+}$cells are still LB1- $($arrow in $C)$. Scale bar $=40 \mu \mathrm{m}$.

proportion of $\mathrm{O}-2 \mathrm{~A}$ progenitors had already migrated out from several cell clusters a few hours after plating (Fig. $3 A, B$ ). The vast majority of the migratory $\mathrm{O}-2 \mathrm{~A}$ progenitors were nestin ${ }^{+}$/ $\mathrm{LB1}^{+}$(Fig. $3 A, B$ ). When cortical O-2A progenitors were cultured in the presence of mitogenic factors (either B104-CM or PDGF + bFGF) for $3 \mathrm{~d}$, a small but significant percentage of cells with a bipolar morphology and with a nestin ${ }^{+} / \mathrm{LB1}{ }^{-}$phenotype were still present (Fig. 3C,D). The bipolar morphology of these cells and the intracellular nestin distribution were very similar to those of $\mathrm{LB1}^{+} /$nestin $^{+}$progenitors (see below), except that their processes were typically shorter. The quantitative analysis revealed that $2.1 \pm 0.3 \%$ of cortical $\mathrm{O}-2 \mathrm{~A}$ were nestin ${ }^{+}$but $\mathrm{LB}^{-}$ still after $3 \mathrm{~d}$ in culture.

After $3 \mathrm{~d}$, cortical O-2A progenitors cultured in the presence of B104-CM were dividing rapidly and displayed a bipolar morphology (Fig. $4 A-D$ ). Both LB1 and anti-nestin antibodies intensely stained these cells (Fig. $4 A-D$ ). The intracellular distribution of nestin in $\mathrm{O}-2 \mathrm{~A}$ progenitors was consistent with the protein being an intermediate filament component in these cells: the protein staining pattern revealed a substantial perinuclear accumulation and a filamentous distribution both in the cell body and in the processes (Fig. 4B,D). A similar staining pattern was observed in O-2A progenitor cells cultured in the presence of PDGF + bFGF for $3 \mathrm{~d}$ (data not shown). Nestin immunoreactivity was only rarely detected in either $\mathrm{O}^{+}{ }^{+}$or $\mathrm{O}^{+}$oligodendrocyte lineage cells. Figure 5 shows that, after withdrawal of mitogenic factors for 3-6 d, $\mathrm{O}^{+}$cells were not stained with anti-nestin antibodies. In the same cultures, the very small number of O-2A progenitors that was still present after several days in culture was intensely stained with anti-nestin antibodies (Fig. $5 B$; see also quantitative analysis below).

Similar to our findings with cortical O-2A progenitors, nestin expression was downregulated in CG-4 cells during their maturation (Fig. 6). CG-4 cells undergo the same morphological and antigenic changes as primary O-2A progenitors during their differentiation into mature oligodendrocytes (Louis et al., 1992a,b; Gallo et al., 1994; Patneau et al., 1994). Figure 6 shows the transition from bipolar $\mathrm{LB}^{+}$cells to multipolar $\mathrm{O}^{+}{ }^{+}$cells. At early developmental stages, CG-4 cells maintained in B104$\mathrm{CM}$ were intensely stained with anti-nestin antibodies(Fig. 6A,B). 

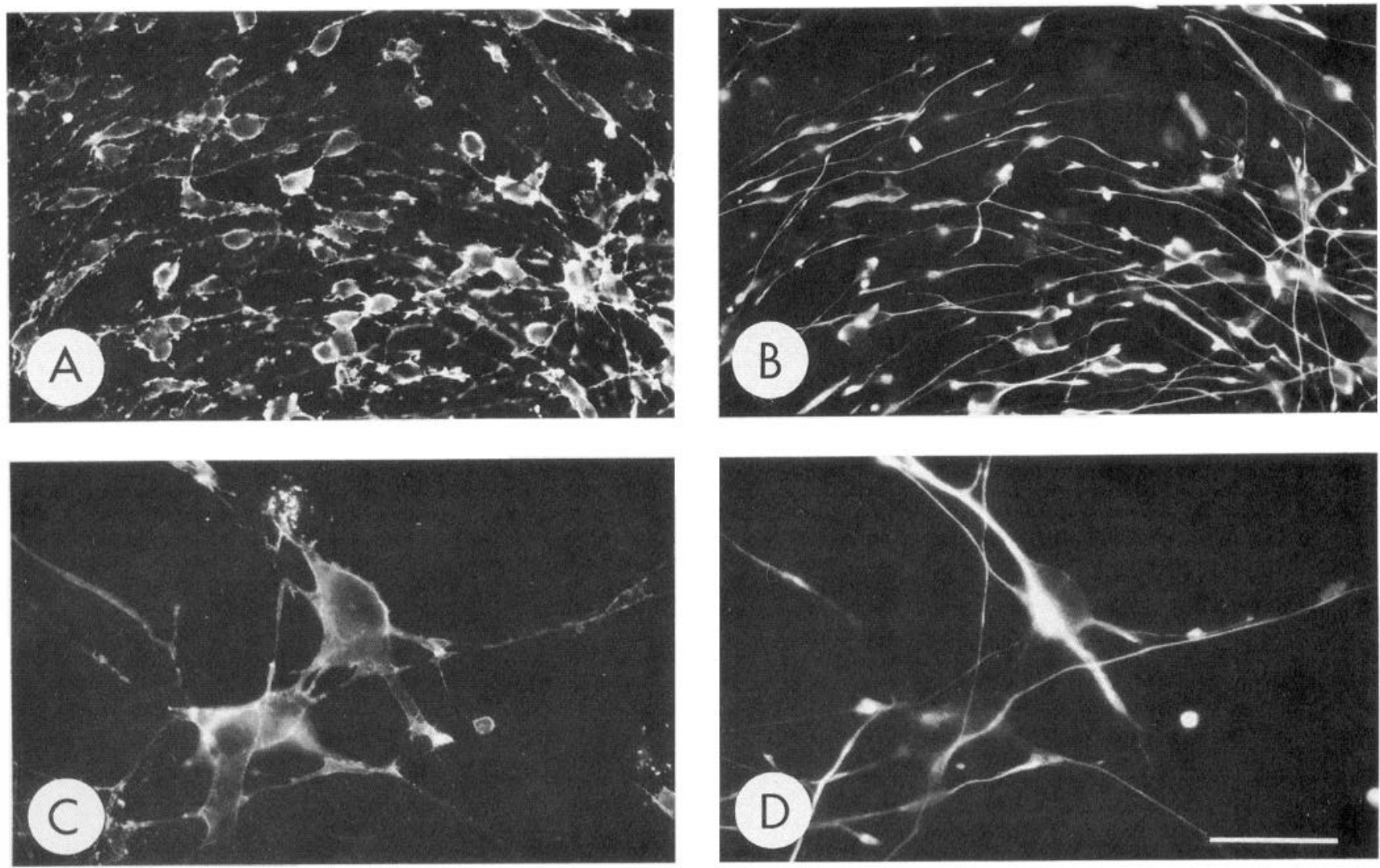

Figure 4. O-2A progenitors maintain nestin expression when culturea in the presence of mitotic agents. Immunofluorescence of cortical O-2A progenitors cultured in $30 \% \mathrm{~B} 104-\mathrm{CM}$ for $3 \mathrm{~d}$. Double staining with LB1 $(A, C)$ and anti-nestin antibodies $(B, D)$. All the LB1 ${ }^{+} \mathrm{O}-2 \mathrm{~A}$ progenitors are also nestin ${ }^{+}$. Anti-nestin antibodies stain intracellular fibrils within the $\mathrm{LB}^{+}$cell bodies and processes. Scale bar $=100 \mu \mathrm{m}$ in $A$ and $B ; 40$ $\mu \mathrm{m}$ in $C$ and $D$.

The nestin intracellular distribution was identical to that observed in cortical O-2A progenitor cells (cf. Fig. 6 and Fig. 4). Also in CG-4 cultures, a small but significant proportion (7.5 $\pm 2.1 \%$ ) of bipolar nestin ${ }^{+} / \mathrm{LB} 1^{-}$cells was present after $3 \mathrm{~d}$ in culture. Finally, $\mathrm{O}^{+}{ }^{+}$cells in $\mathrm{CG}-4$ cultures did not express detectable levels of nestin (Fig. 6C,D).

A quantitative estimate of the phenotypes comprising the nestin $^{+}$cell population demonstrated that, after withdrawal of mitogens, a clear-cut decline in the percentage of nestin ${ }^{+}$cells was observed as the oligodendrocyte lineage cells acquired O4 immunoreactivity. Cultures were double immunostained with anti-nestin antiserum and antibodies that labeled oligodendrocytes at different developmental stages. The results obtained both from cultures of cortical oligodendrocyte lineage cells and CG-4 cells are summarized in Figure 7. In both types of cultures, more than $99 \%$ of $\mathrm{LB1}^{+}$cells were also nestin ${ }^{+}$, but this high
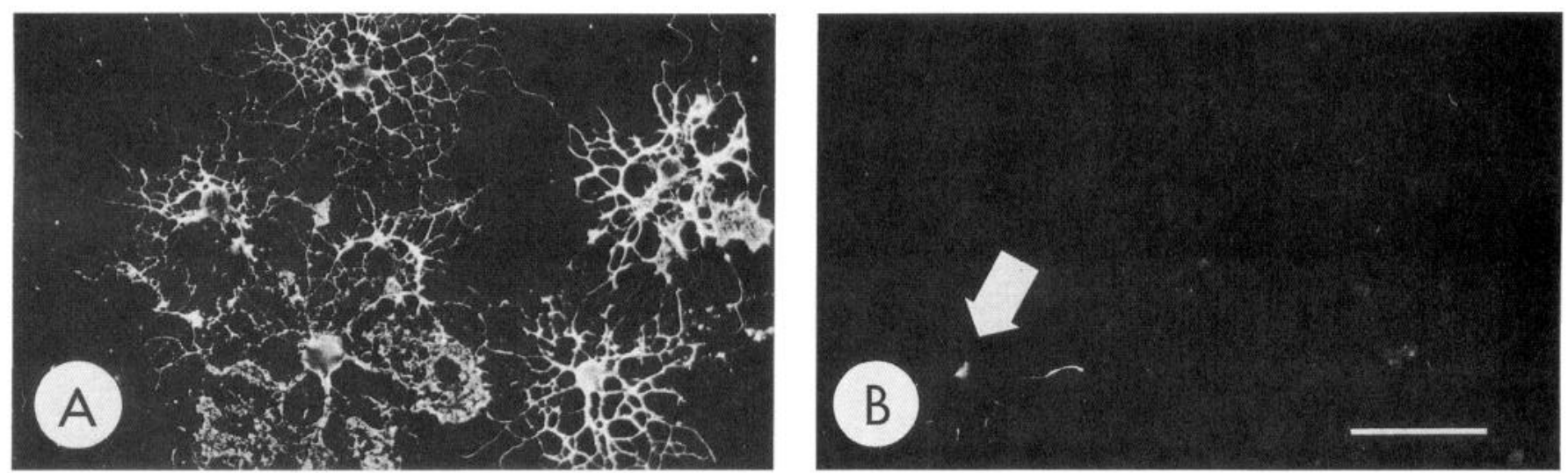

Figure 5. Downregulation of nestin expression in $\mathrm{O}^{+}$cells. Immunofluorescence of cortical oligodendrocytes maintained in vitro for 6 d. Cells were cultured in $30 \%$ B104-CM for $3 \mathrm{~d}$, followed by N1 + 2\% fetal bovine serum for $3 \mathrm{~d}$. Double staining with $\mathrm{O} 4(A)$ and anti-nestin antibodies $(B)$. Nestin protein is undetectable in the majority of $\mathrm{O}^{+}$cells. Some nestin ${ }^{+} \mathrm{O}-2 \mathrm{~A}$ progenitors are still present in the cultures $($ arrow in $B)$. Scale bar $=100 \mu \mathrm{m}$. 

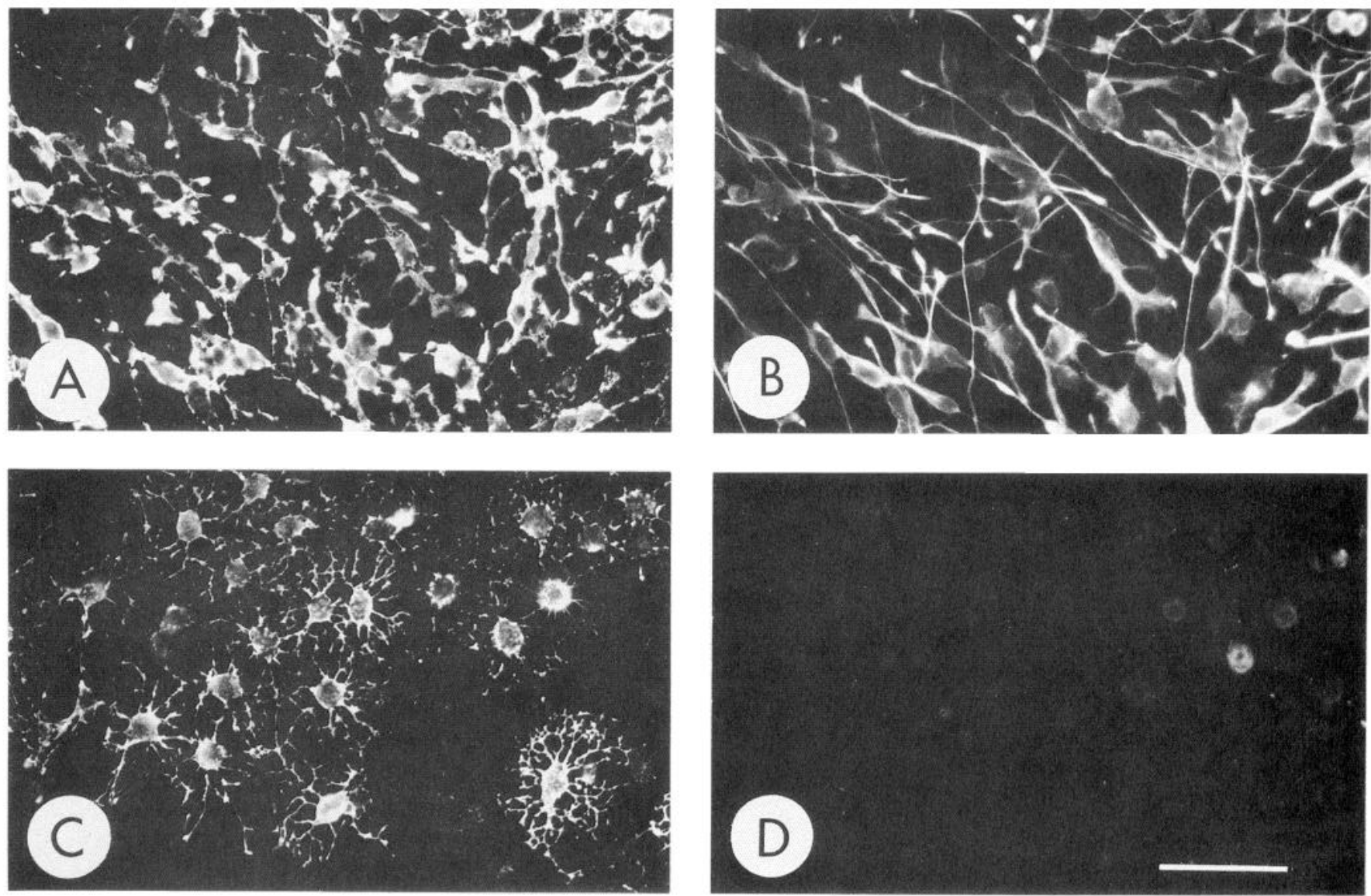

Figure 6. In CG-4 cultures, nestin is expressed in dividing O-2A progenitors, but is attenuated in O4+ cells. Immunofluorescence of CG-4 cells cultured in $30 \%$ B104-CM for $3 \mathrm{~d}(A, B)$ or in B104-CM for $3 \mathrm{~d}$, followed by N1 $+2 \%$ fetal bovine serum for $3 \mathrm{~d}(C, D)$. Double staining with $\mathrm{LB1}(A)$ and anti-nestin $(B)$ or $\mathrm{O} 4(C)$ and anti-nestin $(D)$ antibodies. $\mathrm{LB1}{ }^{+} \mathrm{O}-2 \mathrm{~A}$ progenitors derived from the CG-4 cell line are nestin ${ }^{+}$, whereas the majority of $\mathrm{O}^{+}$cells are nestin ${ }^{-}$. Scale bar $=100 \mu \mathrm{m}$.

percentage dropped to $6.5 \pm 0.7 \%$ and $9.5 \pm 0.8 \%$ of $\mathrm{O}^{+}$cells in cortical and CG-4 cultures, respectively (Fig. $7 A, B$ ). The percentage of $\mathrm{O}^{+} /$nestin $^{+}$cells was even lower, $3.8 \pm 0.6 \%$ in cortical and $1.3 \pm 0.2 \%$ in CG-4 cells (Fig. $7 A, B$ ).

Quantitative analysis of nestin expression relative to cell proliferation was determined by BUdR labeling of cortical oligodendrocyte lineage cells cultured in the presence of PDGF + bFGF for $3 \mathrm{~d}$. Under these culture conditions, the majority of cells are proliferating nestin ${ }^{+} \mathrm{O}-2 \mathrm{~A}$ progenitors. Only $9.7 \pm$ $1.6 \%$ of all nestin ${ }^{+}$cells did not incorporate detectable levels of BUdR. Under the same culture conditions, a small population of cells acquired $\mathrm{O} 4$ immunoreactivity with time in culture. Quantitative analysis of $\mathrm{O}^{+}$cells showed that $15 \pm 2 \%$ of all the $\mathrm{O}^{+}{ }^{+}$cells also expressed nestin, while $28 \pm 5 \%$ of the ${ }^{+}$ cells were $\mathrm{BUdR}^{+}$.

\section{Nestin expression in astrocytes}

Primary astrocyte cultures obtained from neonatal rat cerebral cortex were double stained with anti-nestin and anti-GFAP antibodies. At confluency, most of the cells expressed nestin and approximately $85 \%$ of the nestin ${ }^{+}$cells were also GFAP ${ }^{+}$(Fig. $8 A, B)$. All these nestin ${ }^{+}$cells were $\mathrm{LB1}^{-}$(data not shown) and displayed a polygonal, flat morphology, characteristic of type 1 astrocytes (Raff et al., 1983; Levi et al., 1986; Curtis et al., 1988; Gallo and Bertolotto, 1990). In the cells that expressed nestin and GFAP, the two proteins appeared to be largely colocalized
(Fig. $8 A-F$ ). In these astrocytes, both nestin and GFAP were organized in a filamentous network that extended from the perinuclear region into the entire cell body. Nestin ${ }^{+} /$GFAP $^{-}$cells (approximately $15 \%$ of the total nestin ${ }^{+}$cells) were also present in these cortical astrocyte cultures and often appeared binuclear (Fig. $8 D$ ), presumably reflecting ongoing cell division. In astrocyte cultures stained with anti-Thy-1 antibodies (Pruss et al., 1979), less than $0.5 \%$ of the total cells were labeled (data not shown), which indicates that the nestin ${ }^{+} /$GFAP $^{-}$cells are unlikely to be fibroblasts. Finally, a small percentage of process-bearing $\mathrm{GFAP}^{+}$cells was also present in cortical astrocyte cultures (Fig. $8 E, F)$. These cells were also stained with the monoclonal antibody LB1 (data not shown) and could, therefore, be classified as type 2 astrocytes (Levi et al., 1986; Curtis et al., 1988; Gallo and Bertolotto, 1990). Interestingly, none of the process-bearing, $\mathrm{GFAP}^{+}$type 2 astrocytes expressed nestin (Fig. 8E,F).

\section{Early oligodendrocyte lineage cells express nestin in vivo}

To determine the extent of nestin expression in oligodendrocyte lineage cells in vivo, we examined immunostained tissue sections and tissue print preparations (Figs. 9, 10). Consistent with a previous report (Hockfield and McKay, 1985), we found that nestin expression in early postnatal spinal cord is limited mainly to radially oriented cells in the midline. Similar results were found in sections of postnatal day 3 and 7 cervical spinal cord 
immunostained with either the monoclonal or the polyclonal antisera against nestin (see Fig. 9A). In contrast, at postnatal days 3 and 7 nestin is highly expressed in cells throughout the brain. The majority of nestin ${ }^{+}$cells in the brain appear to be radial glial cells that are $\mathrm{GFAP}^{+}$(Fig. $9 B, C$ ), as previously reported (Hockfield and McKay, 1985). However, it is difficult in this type of preparation to identify developing oligodendrocyte lineage cells and assess the corresponding nestin expression. Previous studies have demonstrated that the antibodies routinely used to characterize specific developmental stages in the oligodendrocyte lineage in vitro can be problematic when applied in situ. For example, $\mathrm{O} 4$ and $\mathrm{O} 1$ react with additional antigens in fresh-frozen or live tissue sections, respectively (Sommer and Schachner, 1981; Warrington and Pfeiffer, 1992).

To definitively examine nestin expression in vivo at specific stages of oligodendrocyte lineage maturation corresponding to our in vitro analysis, we immunostained cells in tissue print preparations from postnatal day 3 and day 5 rat brain (Fig. 10). Fresh coronal brain slices were subjected to mild enzymatic digestion before being touched to the surface of a precoated coverslip, which was then immediately fixed in paraformaldehyde. Since the tissue prints are acute preparations, the cells maintain their in vivo antigenic phenotype (Barres et al., 1990; Armstrong, unpublished observations). As expected from the tissue section analysis (Fig. 10) and previous studies (Hockfield and McKay, 1985), the majority of nestin ${ }^{+}$cells in the tissue prints were also $\mathrm{GFAP}^{+}$and appeared to be radial glia, while large cells with a neuronal morphology did not exhibit nestin immunoreactivity (data not shown). However, nestin expression was apparent in oligodendrocyte lineage precursor cells. Cells with a phenotype of $\mathrm{O}-2 \mathrm{~A}$ progenitors were identified in the tissue prints as small bipolar or multipolar cells with strong surface A2B5 immunoreactivity (Fig. 10A,B). These cells consistently contained intracellular fibrils that were immunostained with anti-nestin antibodies (Fig. 10C). Late oligodendrocyte progenitors, or pro-oligodendroblasts, were identified in tissue prints as multipolar cells with surface $\mathrm{O} 4$ immunoreactivity (Fig. $10 D, E$ ) in the absence of RmAb immunoreactivity. Many of these pro-oligodendroblasts also expressed nestin (Fig. 10F). O4 immunoreactivity is maintained as cells mature beyond the pro-oligodendroblast stage. More mature oligodendrocytes acquire galactocerebroside, recognized by $\mathrm{RmAb}$ or $\mathrm{Ol}$. The majority of $\mathrm{RmAb}^{+}$and $\mathrm{Ol}^{+}$cells, presumably oligodendrocytes, did not contain nestin ${ }^{+}$intracellular fibrils (Fig. 10G-I).

Quantitation of nestin expression in oligodendrocyte lineage cells from tissue prints clearly demonstrated that nestin expression decreases during the pro-oligodendroblast stage, which is consistent with our in vitro findings. In tissue prints from postnatal day 5 rat brains, $50.6 \pm 12.9 \%$ of the total population of $\mathrm{O}^{+}$oligodendrocyte lineage cells had already progressed to the $\mathrm{RmAb}^{+}$stage and were negative for nestin. $\mathrm{O}^{+} / \mathrm{RmAb}^{+}$ cells with detectable nestin immunoreactivity were found only occasionally $(4.0 \pm 3.5 \%$ of all $\mathrm{O} 4+$ cells $)$. Pro-oligodendroblasts $\left(\mathrm{O}^{+} / \mathrm{RmAb}^{-}\right)$were either nestin ${ }^{+}\left(23.8 \pm 10.6 \%\right.$ of all $\mathrm{O}^{+}$ cells) or nestin ${ }^{-}\left(21.5 \pm 4.7 \%\right.$ of all $\mathrm{O}^{+}$cells). Thus, the majority of the oligodendrocyte lineage cells lose nestin expression during the pro-oligodendroblast stage, and nestin persists only at later stages in a small percentage of cells.

\section{Discussion}

The expression of nestin in developing CNS neurons has been previously studied (Hockfield and McKay, 1985; Fredriksen and
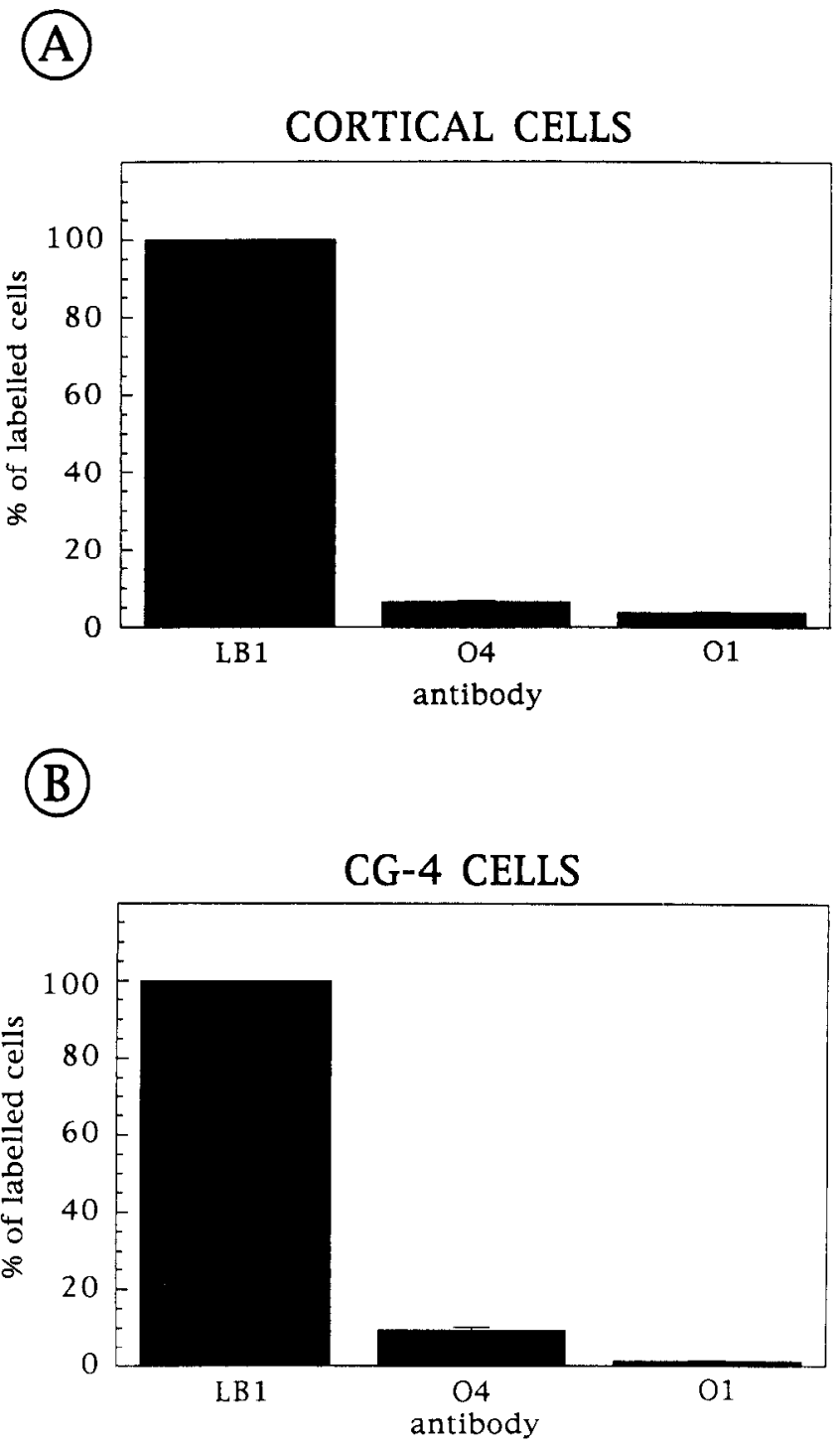

Figure 7. Developmental regulation of nestin expression in cells of the oligodendrocyte lineage. Cortical cultures $(A)$ and CG-4 cells $(B)$. Cells were double stained with $\mathrm{LB} 1, \mathrm{O} 4$, or $\mathrm{O} 1$ plus anti-nestin antibodies at 3,6 , and $8 \mathrm{~d}$ in culture, respectively. Values represent the percentage of the cells stained by $\mathrm{LBl}, \mathrm{O} 4$, or $\mathrm{Ol}$, as indicated, that are also stained by anti-nestin. Nestin expression is drastically downregulated in the $\mathrm{O}^{+}$and the $\mathrm{O}^{+}$populations. Averages from three independent experiments are presented. Bars indicate SEM.

McKay, 1988; Lendhal et al., 1990). In neuroepithelial precursor cells this protein is abundantly expressed, but drastically downregulated in postmitotic, differentiating neurons (Hockfield and McKay, 1985; Lendhal et al., 1990), indicating that regulation of nestin gene expression occurs at critical phases of neural cell development. In glia, however, it is not known how and when nestin expression is regulated during development. We have chosen to examine nestin expression and regulation in a particular subclass of glial cells, the oligodendrocytes. These cells offer the following advantages (reviewed in Dubois-Dalcq and Armstrong, 1992) for analysis of glial cell development: (1) oligodendrocyte progenitors $(\mathrm{O}-2 \mathrm{~A})$ can be purified and cultured under specified conditions that promote their proliferation and/or differentiation; (2) O-2A progenitor maturation into oligodendrocytes occurs with approximately the same time schedule in 

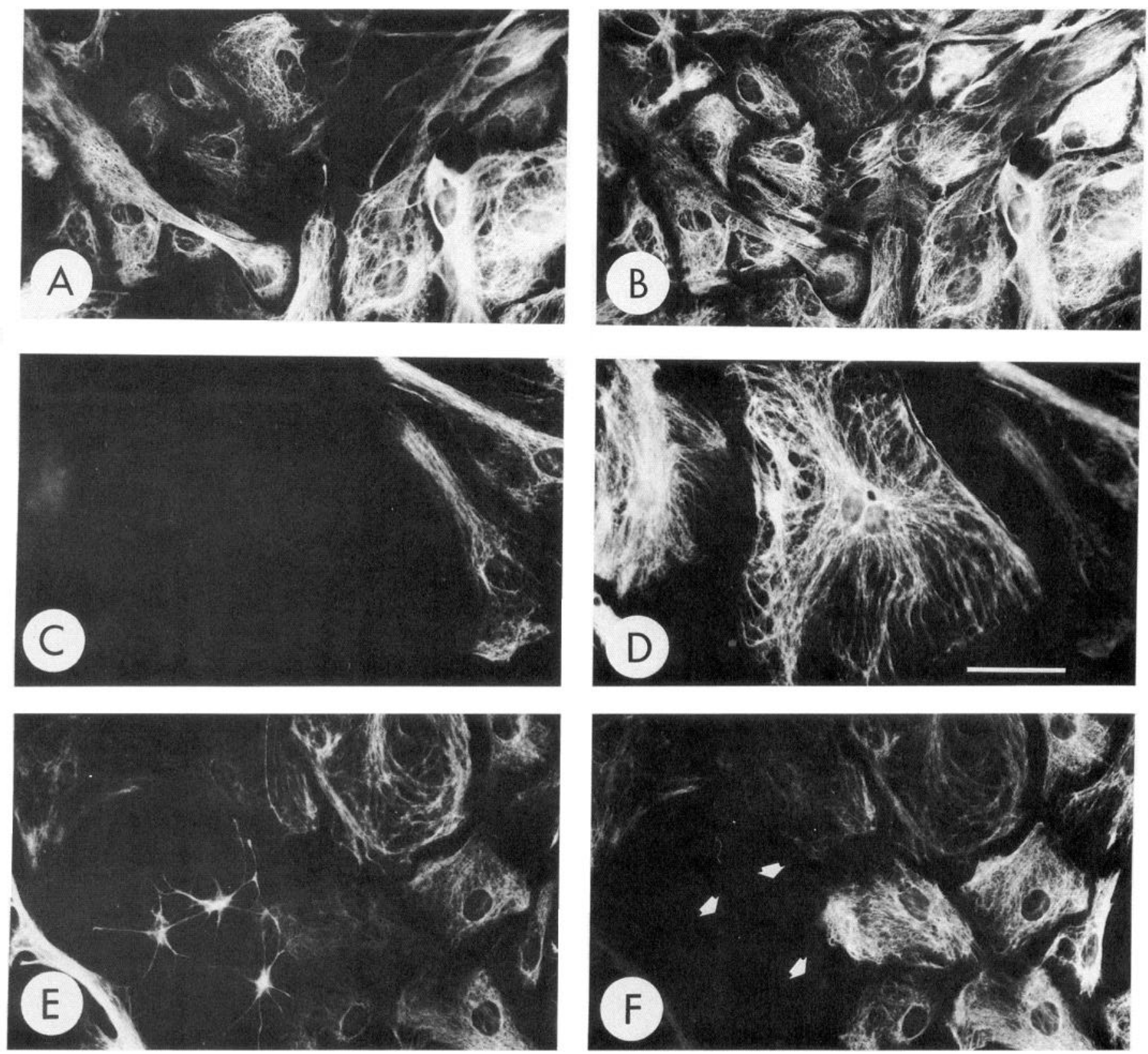

Figure 8. Expression of nestin in cortical astrocytes. Immunofluorescence staining of cortical astrocytes cultured for $14 \mathrm{~d}$. Cells were double stained with anti-GFAP $(A, C, E)$ and anti-nestin antibodies $(B, D, F)$. The majority of type 1 astrocytes exhibit colocalized expression of nestin and GFAP $(A, B)$. Nestin ${ }^{+}(B, D)$, GFAP- $(A, C)$ cells were evident in the cultures. Some of the nestin ${ }^{+} / \mathrm{GFAP}^{-}$cells are binuclear $(D)$, presumably indicative of ongoing cell division. Type 2 astrocytes are GFAP+ $(E)$ and nestin- $(F$, arrows $)$. Scale bar $=100 \mu \mathrm{m}$ in $A, B, E$, and $F ; 40 \mu \mathrm{m}$ in $C$ and $D$.

vivo and in vitro; (3) $\mathrm{O}-2 \mathrm{~A}$ progenitor differentiation progresses through several stages, which can be identified by the sequential expression of developmentally regulated antigens; and (4) growth factors that increase $\mathrm{O}-2 \mathrm{~A}$ progenitor proliferation and prevent their differentiation have been identified.

Our study of nestin in developing oligodendrocytes in vitro and in vivo unequivocally shows that this intermediate filament protein is abundantly expressed in dividing $\mathrm{O}-2 \mathrm{~A}$ progenitor cells, but sharply downregulated at the pro-oligodendroblast stage. The single nestin mRNA band present in oligodendrocyte progenitors is identical in size to that found in postnatal day 1 rat cortex (Fig. 1A) and in embryonic rat brain and cerebellum (Lendhal et al., 1990). This indicates that similar RNA pro- cessing occurs in cells of the oligodendrocyte lineage in culture and in vivo. We found a close correlation between nestin mRNA and protein levels in O-2A cells and observed that each of the growth factors that increased nestin mRNA expression also upregulated the protein (see below). The immunostaining pattern obtained in $\mathrm{O}-2 \mathrm{~A}$ lineage cells with anti-nestin antibodies was similar to that described in other neural precursor cells (Lendhal et al., 1990; Reynolds et al., 1992) and indicates that nestin is a component of cytoskeleton in oligodendrocyte lineage cells.

Cells in a pre-O-2A developmental stage have been previously described as highly proliferative cells that express polysialylated neural cell adhesion molecule (N-CAM), but do not express 

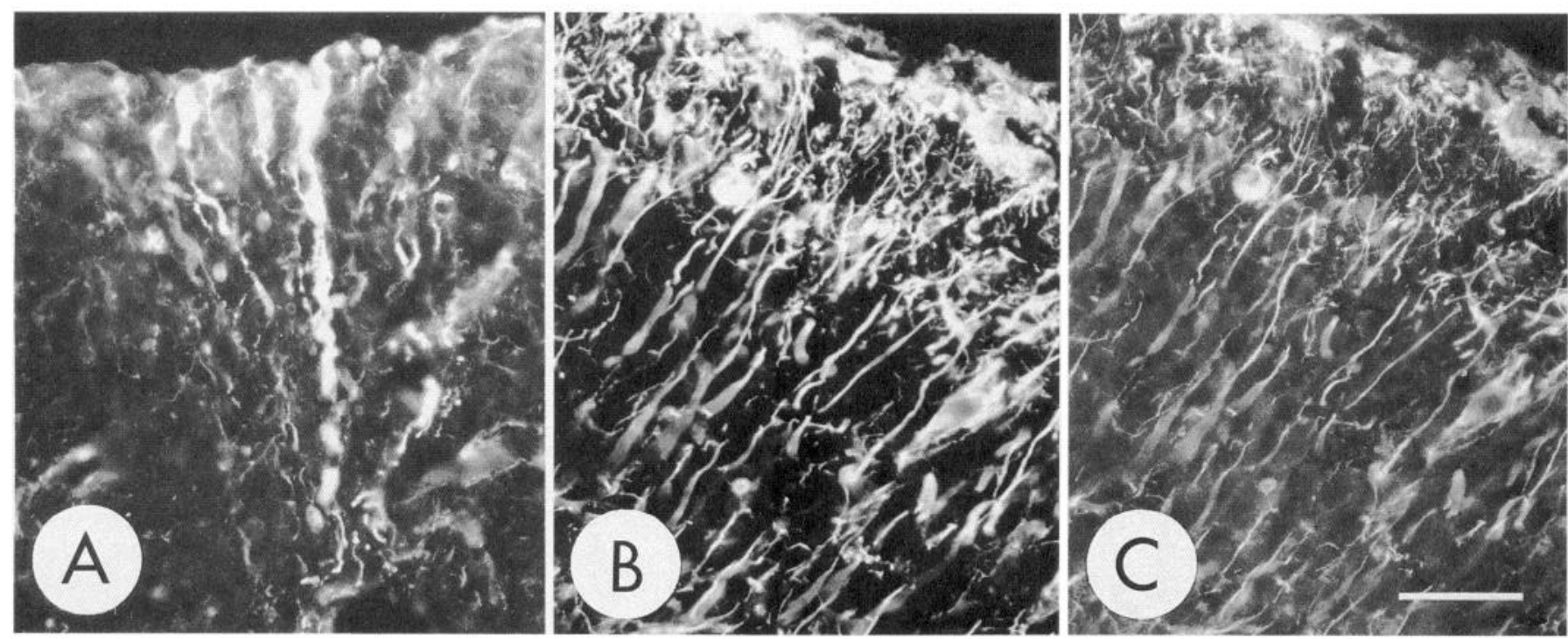

Figure 9. Expression of nestin protein in early postnatal CNS. A, Transverse sections of postnatal day 7 rat cervical spinal cord immunostained with the rat-401 monoclonal anti-nestin antibody. Intense nestin immunoreactivity is observed in cells along the midline (dorsal funiculus shown). $B, C$, Double indirect immunofluorescence of a coronal section of postnatal day 3 rat cerebral cortex. Intense colocalized staining of radially oriented cells was observed using a rabbit polyclonal anti-nestin antibody $(B)$ and an anti-GFAP mouse monoclonal antibody $(C)$. Scale bar $=50 \mu \mathrm{m}$.

GD3 (Trotter et al., 1989; Grinspan et al., 1990; Hardy and Reynolds, 1991). After a few hours in vitro, our cortical cultures comprised several clusters of cells, presumably pre-O-2A, that expressed nestin, but not GD3. In similar culture conditions, these clustered cells also expressed the polysialylated N-CAM (Armstrong, unpublished observations). After longer culture periods, the majority of nestin ${ }^{+}$cells were stained with LB1 antiGD3 antibody (Fig. 4) or with the A2B5 monoclonal antibody (data not shown), as previously demonstrated by Almazan et al. (1993). However, a population of nestin ${ }^{+/ L B 1} 1^{-}$cells persisted after $3 \mathrm{~d}$ in cultures treated with mitogenic factors (either B104-CM or PDGF + bFGF; Fig. 3), possibly indicating that this small pool of cells is capable of self-renewal. When mitogenic factors were used, which also prevented O-2A progenitors from differentiating (Bogler et al., 1990; Hunter and Bottenstein, 1990; McKinnon et al., 1990), nestin mRNA expression was maintained at high levels (Fig. 2). It has been previously indicated that the effects of $\mathrm{B} 104-\mathrm{CM}$ on $\mathrm{O}-2 \mathrm{~A}$ progenitor proliferation are likely to involve as yet unidentified molecules (Hunter and Bottenstein, 1990). The mechanism by which growth factors can enhance nestin expression remains to be determined.

Nestin expression is sharply downregulated in $\mathrm{O}^{+}$oligodendrocyte lineage cells (oligodendroblasts and oligodendrocytes), which have a multipolar morphology and slower proliferation rate (Dubois-Dalcq, 1987; Gard and Pfeiffer, 1990). In our cortical cell cultures, only $6 \%$ of the total $\mathrm{O}^{+}{ }^{+}$cells were also nestin ${ }^{+}$, and in this small cell population both antigens were expressed at low levels, suggesting that this phenotype was transitional between $\mathrm{O}_{4}^{-} /$nestin $^{+}$and $\mathrm{O}^{+} /$nestin $^{-}$. Nestin mRNA levels are extremely low in cultures containing more than $90 \%$ of O4+ cells (Fig. 2, lane 1), confirming that the $\mathrm{O} 4$ monoclonal antibody identifies the critical developmental stage at which nestin expression is attenuated. In galactocerebroside ${ }^{+}\left(\mathrm{O} 1^{+}\right)$, differentiated oligodendrocytes, nestin expression was restricted to an even lower percentage of cells (Fig. 7), in agreement with a recent report by Almazan et al. (1993).
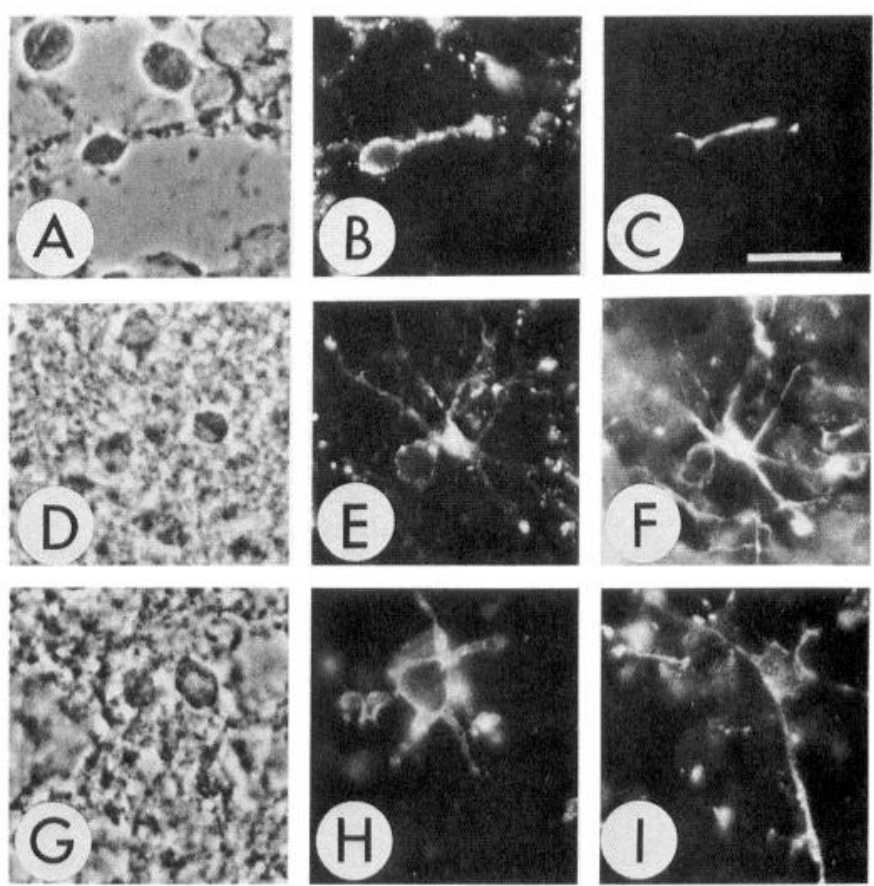

Figure 10. Expression of nestin protein in tissue prints from postnatal rat brain. $A-C$, Phase-contrast $(A)$ and double indirect immunofluorescence $(B, C)$ using the A2B5 monoclonal antibody $(B)$ and rat-401 antinestin monoclonal antibody $(C)$. This field shows an example of an $\mathrm{A} 2 \mathrm{~B} 5^{+}$cell that is also nestin ${ }^{+} . D-F$, Phase-contrast $(D)$ and double indirect immunofluorescence $(E, F)$ using the $\mathrm{O} 4$ monoclonal antibody $(E)$ and an anti-nestin polyclonal antibody $(F)$. An example is shown of a process-bearing $\mathrm{O}_{4}{ }^{+} /$nestin $^{+}$cell. $G-I$, Phase-contrast $(G)$ and triple indirect immunofluorescence $(H, I)$ using the $\mathrm{O} 4$ monoclonal antibody (not shown), the $\operatorname{RmAb}(H)$, and an anti-nestin polyclonal antibody $(I)$. An example is shown of a process-bearing $\mathrm{O}^{+} / \mathrm{RmAb}^{+} /$nestin $^{-}$cell. Scale bar $=50 \mu \mathrm{m}$. 
Our analysis of nestin expression in tissue sections and tissue prints confirms previous findings by Hockfield and McKay (1985) in radial glia, but also demonstrates that developing oligodendrocyte lineage cells express nestin in situ. In tissue prints, O-2A progenitors $\left(\mathrm{A} 2 \mathrm{~B}^{+}{ }^{+}\right.$cells) were intensely stained with anti-nestin antibodies, whereas $\mathrm{RmAb}^{+}$or $\mathrm{Ol}^{+}$oligodendrocytes only rarely expressed nestin, in agreement with our findings in cultured cells. This transition from nestin ${ }^{+}$to nestin- appeared to occur during the $\mathrm{O}^{+}$stage, because $\mathrm{O}^{+} / \mathrm{RmAb}^{-}$pro-oligodendroblasts were present as both nestin ${ }^{+}$and nestin ${ }^{-}$phenotypes. These in situ findings are in agreement with our in vitro results. The $\mathrm{O}^{+}$population present in our cultures may be comprised of pro-oligodendroblasts and oligodendrocytes, because $\mathrm{O} 4 \mathrm{rec}-$ ognizes not only the pro-oligodendroblast antigen, but also sulfatide, which is expressed by oligodendrocytcs (Bansal et al., 1989). It should be noted that we also found a small percentage of $\mathrm{O}^{+} /$nestin $^{+}$cells in culture (Fig. 7). Although we did not attempt to directly identify nestin ${ }^{+}$cells as oligodendrocyte precursors in tissue sections, our tissue culture and tissue print analyses indicate that anti-nestin antibodies would label early oligodendrocyte progenitors in vivo. However, nestin expression is not restricted to the oligodendrocyte lineage and is widely expressed relative to PDGF $\alpha$-receptors and DM-20, which have been reported as markers of early oligodendrocyte lineage cells (Pringle et al., 1992; Timsit et al., 1992).

The developmental regulation of nestin observed in cortical oligodendrocytes was completely reproduced in the CG-4 cell line. CG-4 cells can be kept in their O-2A state by exposure to B104-CM or PDGF + bFGF (Louis et al., 1992a; Patneau et al., 1994), and then differentiated into $\mathrm{O}^{+}$pro-oligodendroblasts by withdrawing the mitogenic factors. These cells become mature, myelin-synthesizing oligodendrocytes within a few days in culture (Louis et al., 1992a; Tontsch et al., 1994). CG-4 cells are also very similar to cortical $\mathrm{O}-2 \mathrm{~A}$ progenitors and oligodendrocytes in several of their functional properties (Gallo et al., 1994; Patneau et al., 1994; Pende et al., 1994), and have been shown to retain the migratory and myelinating potential of O-2A progenitors when transplanted in spinal cord of myelindeficient rats (Tontsch et al., 1994). Similar to cortical oligodendrocytes, nestin is expressed in bipolar CG-4 cells and downregulated in $4^{+} \mathrm{CG}-4$ cells, both at the mRNA and protein levels. Finally, the significant percentage of nestin ${ }^{+} / \mathrm{LB1}^{-}$cells present in CG-4 cultures after a few days in vitro may represent a pool of pre-O-2A cells that is capable of self-renewal in repeatedly passaged cultures.

Nestin mRNA and protein are also expressed in astrocytes (Figs. 1, 8). The two major subpopulations of astrocytes in culture, type 1 and type 2, proliferate at different rates and, after a few days in culture, only type 1 are still dividing (Wilkin et al., 1983). In our analysis we did not correlate nestin expression with astrocyte proliferation rate, but nestin appears to be associated with dividing cells, because type 2 astrocytes did not express nestin mRNA (data not shown) or protein (Fig. 8). The presence of a significant pcrcentage of nestin ${ }^{+} / \mathrm{GFAP}^{-}$type 1 astrocytes suggests that this may represent a dedifferentiated phenotype similar to that found in several CNS tumor cell lines (Tohyama et al., 1992).

In conclusion, our analysis of nestin expression and regulation in a developmentally well defined glial cell population indicates that nestin is downregulated during the $\mathrm{O}^{+}$pro-oligodendroblast developmental stage. In the oligodendrocyte differentiation pathway, cells of this antigenic phenotype correspond to post- migratory oligodendroblasts in vivo (Warrington and Pfeiffer, 1992). The high levels of nestin expression in actively proliferating $\mathrm{O}-2 \mathrm{~A}$ progenitors suggest that this intermediate filament protein may have a similar functional role in glial as well as neuronal progenitors. It is tempting to speculate that nestin may be important to maintain cytoskeletal plasticity and maximal motility of $\mathrm{O}-2 \mathrm{~A}$ progenitor cells during their migratory phase. GAP-43 (neuromodulin), which is also thought to be involved in growth and remodeling, is similarly downregulated in $\mathrm{O}^{+}$ oligodendroblasts (Deloulme et al., 1990). However, PDGF and bFGF each similarly enhanced nestin mRNA expression, while only PDGF can induce O-2A progenitor migration (Armstrong et al., 1990b). Therefore, nestin expression may not be directly involved in migration. Accordingly, our findings are suggestive of a yet to be defined role for nestin in proliferating glial progenitor cells. CG-4 cells should serve as a particularly useful model for further studies of nestin gene regulation (see Lendhal et al., 1990; Dahlstrand et al., 1992; Zimmerman et al., 1994) and nestin function.

\section{References}

Almazan G, Afar DEH, Bell JC (1993) Phosphorylation and disruption of intermediate filament proteins in oligodendrocyte precursor cultures treated with calyculin A. J Neurosci Res 36:163-172.

Armstrong RC, Friedrich VL, Holmes KV Jr, Dubois-Dalcq M (1990a) In vitro analysis of the oligodendrocyte lineage in mice during demyelination and remyelination. J Cell Biol 111:1183-1195.

Armstrong RC, Harvath L, Dubois-Dalcq M (1990b) Type 1 astrocytes and oligodendrocyte-type 2 astrocyte glial progenitors migrate toward distinct molecules. J Neurosci Res 27:400-407.

Armstrong RC, Dorn HH, Kufta CV, Friedman E, Dubois-Dalcq ME (1992) Pre-oligodendrocytes from adult human CNS. J Neurosci 12: $1538-1547$

Bansal R, Pfeiffer SE (1992) Novel stage in the oligodendrocyle lineage defined by reactivity of progenitors with $\mathrm{R}-\mathrm{mAb}$ prior to $\mathrm{O} 1$ antigalactocerebroside. J Neurosci Res 32:309-316.

Bansal R, Warrington A, Gard AL, Ranscht B, Pfeiffer SE (1989) Multiple and novel specificities of monoclonal antibodies $\mathrm{O} 1, \mathrm{O} 4$ and $\mathrm{R}-\mathrm{mAb}$ used in the analysis of oligodendrocyte development. J Neurosci Res 24:548-557.

Barres BA, Koroshtetz WJ, Swartz KJ, Chun LLY, Corey DP (1990) Ion channel expression by white matter glia: the O-2A glial progenitor cell. Neuron 4:507-524.

Bogler O, Wren D, Barnett SC, Land H, Noble M (1990) Cooperation between two growth factors promotes extended self-renewal and inhibits differentiation of oligodendrocyte-type- 2 astrocyte $(\mathrm{O}-2 \mathrm{~A})$ progenitor cells. Proc Natl Acad Sci USA 87:6368-6372.

Borke RC, Curtis M, Ginsberg C (1993) Choline acetyltransferase and calcitonin gene-related peptide immunoreactivity in motoneurons after different types of nerve injury. J Neurocytol 22:141-153.

Chirgwin JM, Przybyla AE, Macdonald RJ, Rutter WJ (1979) Isolation of biologically active ribonucleic acid from sources enriched in ribonuclease. Biochemistry 18:5294-5299.

Chomczynski P, Sacchi N (1987) Single step method of mRNA isolation acid guanidinium thiocyanate-phenol-chloroform extraction. Anal Biochem 162:156-159.

Curtis R, Cohen J, Fok-Seang J, Hanley MR, Gregson NA, Reynolds $\mathrm{R}$, Wilkin GP (1988) Development of macroglial cells in rat cerebellum. I. Use of antibodies to follow early in vivo development and migration of oligodendrocytes. J Neurocytol 17:43-54.

Dahlstrand J, Zimmerman LB, McKay RDG, Lendhal U (1992) Characterization of the human nestin gene reveals a close evolutionary relationship to neurofilaments. J Cell Sci 103:589-597.

Deloulme JC, Janet T, Au D, Storm DR, Sensenbrenner M, Baudier J (1990) Neuromodulin (GAP43): a neuronal protein kinase $C$ substrate is also present in $\mathrm{O}-2 \mathrm{~A}$ glial cell lineage. Characterization of neuromodulin in secondary cultures of oligodendrocytes and comparison with the neuronal antigen. J Cell Biol 111:1559-1569.

Deloulme JC, Baudier J, Sensenbrenner M (1991) Establishment of 
pure neuronal cultures from fetal rat spinal cord and proliferation of the neuronal precursor cells in the presence of fibroblast growth factor. J Neurosci Res 29:499-509.

Dubois-Dalcq M (1987) Characterization of a slowly proliferative cell along the oligodendrocyte differentiation pathway. EMBO J 6:25872595 .

Dubois-Dalcq M, Armstrong RC (1992) The oligodendrocyte lineage during myelination and remyelination. In: Myelin: biology and chemistry (Martenson RE, ed), pp 81-122. Boca Raton, FL: CRC Press. Eisenbarth GS, Walsh FS, Nirenberg M (1979) Monoclonal antibody of a plasma membrane antigen of neurons. Proc Natl Acad Sci USA 76:4913-4917.

Frederiksen K, McKay RDG (1988) Proliferation and differentiation of rat neuroepithelial precursor cells in vivo. J Neurosci 8:1144-1151.

Frederiksen K, Jat PS, Valtz N, Levy D, McKay RDG (1988) Immortalization of precursor cells from the mammalian CNS. Neuron $1: 439-448$.

Gallo V, Bertolotto A (1990) Extracellular matrix of cultured glial cells: selective expression of chondroitin 4-sulfate by type-2 astrocytes and their progenitors. Exp Cell Res 187:211-223.

Gallo V, Patneau DK, Mayer ML, Vaccarino FM (1994) Excitatory amino acid receptors in glial progenitor cells: molecular and functional properties. Glia, in press.

Gard AL, Pfeiffer SE (1990) Two proliferative stages of the oligodendrocyte lineage (A2B5+ $4^{-}$and $\mathrm{O}^{+}{ }^{+} \mathrm{GalC}$ ) under different mitogenic control. Neuron 5:615-625.

Gard AL, Pfeiffer SE (1993) Glial cell mitogens bFGF and PDGF differentially regulate development of $\mathrm{O} 4{ }^{+} \mathrm{GalC}^{-}$oligodendrocyte progenitors. Dev Biol 159:618-630.

Gensburger C, Labourdette G, Sensenbrenner M (1987) Brain basic fibroblast growth factor stimulates the proliferation of rat neuronal precursor cells in vitro. FEBS Lett 217:1-5.

Goldman JE, Hirano M, Yu RK, Seyfried TN (1984) GD3 ganglioside is a glycolipid characteristic of immature neuroectodermal cells. $J$ Neuroimmunol 7:179-192.

Goldman JE, Scott Geier S, Hirano M (1986) Differentiation of astrocytes and oligodendrocytes from germinal matrix cells in primary culture. J Neurosci 6:52-60.

Grinspan JB, Stern JL, Pustilnik SM, Pleasure D (1990) Cerebral white matter contains PDGF-responsive precursors to $\mathrm{O} 2 \mathrm{~A}$ cells. J Neurosci 10:1866-1873.

Halliday AL, Cepko CL (1992) Generation and migration of cells in the developing striatum. Neuron 9:15-26.

Hardy R, Reynolds R (1991) Proliferation and differentiation of rat forebrain oligodendroglial progenitors both in vitro and in vivo. Development 111:1061-1080.

Hockfield S, McKay RDG (1985) Identification of major cell classes in the developing mammalian nervous system. J Neurosci 5:33103328.

Hunter SF, Bottenstein JE (1990) Growth factor responses of enriched hipotential glial progenitors. Brain Res 54:235-248.

Kilpatrick TJ, Bartlett PF (1993) Cloning and growth of multipotential neural precursors: requirements for proliferation and differentiation. Neuron 10:255-265.

Lendhal U, Zimmerman LB, McKay RDG (1990) CNS stem cells express a new class of intermediate filament protein. Cell 60:585595.

Levi G, Gallo V, Ciotti MT (1986) Bipotential precursors of putative fibrous astrocytes and oligodendrocytes in rat cerebellar cultures express distinct surface features and "neuron-like" GABA transport. Proc Natl Acad Sci USA 83:1504-1508.

LeVine SE, Goldman JE (1988) Spatial and temporal patterns of oligodendrocyte differentiation in rat cerebrum and cerebellum. J Comp Neurol 277:441-455.

Levison SW, Goldman JE (1993) Both oligodendrocytes and astrocytes develop from progenitors in the subventricular zone of postnatal rat forebrain. Neuron 10:201-212.

Louis JC, Magal E, Muir D, Manthorpe M, Varon S (1992a) CG-4, a new bipotential cell line from rat brain, is capable of differentiating in vitro into either mature oligodendrocytes or type- 2 astrocytes. J Neurosci Res 31:193-204.

Louis JC, Muir D, Varon S (1992b) Autocrine inhibition of mitotic activity in cultured oligodendrocyte-type- 2 astrocyte $(\mathrm{O}-2 \mathrm{~A})$ precursor cells. Glia 6:30-38.

McCarthy KD, de Vellis J (1980) Preparation of separate astroglial and oligodendroglial cell cultures from rat cerebral tissuc. J Cell Biol 85:890-902.

McCarthy GF, Leblond CP (1988) Radioautographic evidence for slow astrocyte turnover and modest oligodendrocyte production in the corpus callosum of adult mice infused with ${ }^{3} \mathrm{H}$-thymidine. J Comp Neurol 271:589-603

McKinnon RD, Matsui T, Dubois-Dalcq M, Aaronson SA (1990) FGF modulates the PDGF-driven pathway of oligodendrocyte development. Neuron 5:603-614.

Patneau DP, Wright PW, Winters C, Mayer ML, Gallo V (1994) Glial cells of the oligodendrocyte lineage express both kainate- and AMPApreferring subtypes of glutamate receptor. Neuron 12:357-371.

Pende M, Holtzclaw LA, Curtis JL, Russell JT, Gallo V (1994) Glutamate regulates intracellular calcium and gene expression in oligodendrocyte progenitors through the activation of $\Lambda$ MP $\Lambda$ receptors. Proc Natl Acad Sci USA 91:3215-3219.

Price J, Thurlow L (1988) Cell lineage in the rat cerebral cortex: a study using retroviral-mediated gene transfer. Development 104:473482.

Pringle NP, Hardeep SM, Collarini EJ, Richardson WD (1992) PDGF receptors in the rat CNS: during late neurogenesis, PDGF alphareceptor expression appears to be restricted to glial cells of the oligodendrocyte lineage. Development 115:535-551.

Pruss R (1979) Thy-1 antigen on astrocytes in long-term cultures of rat central nervous system. Nature 280:688-690.

Raff MC, Mirsky R, Fields KL, Lisak RP, Dorfman SH, Silberberg DH, Gregson NA, Liebowitz S, Kennedy MC (1978) Galactocerebroside is a specific cell surface antigenic marker for oligodendrocytes in culture. Nature 274:813-816.

Raff MC, Miller RH, Noble M (1983) A glial progenitor cell that develops in vitro into an astrocyte or an oligodendrocyte depending on culture medium. Nature 303:390-396.

Raff MC, Lillien LE, Richardson WD, Burne FJ, Noble MD (1988) Platelet-derived growth factor from astrocytes drives the clock that times oligodendrocyte development in culture. Nature 333:562-565.

Ranscht B, Clapshaw PA, Price J, Noble M, Seifert W (1982) Development of oligodendrocytes and Schwann cells studied with a monoclonal antibody against galactocerebroside. Proc Natl Acad Sci USA 79:2709-2713.

Reynolds R, Wilkin GP (1988) Development of macroglial cells in rat cerebellum. II. An in situ immunohistochemical study of oligodendroglial lineage from precursor to mature myelinating cell. Devclopment 102:409-425.

Reynolds BA, Weiss S (1992) Generation of neurons and astrocytes from isolated cells of the adult mammalian central nervous system. Science 255:1707-1710.

Reynolds BA, Tetzlaff W, Weiss S (1992) A multipotent EGF-responsive striatal embryonic progenitor cell produces neurons and astrocytes. J Neurosci 12:4565-4574.

Sauer FC (1935) Mitosis in the neural tube. J Comp Neurol 62:377405.

Sommer I, Schachner M (1981) Monoclonal antibodies (Ol to O4) to oligodendrocyte cell surfaces: an immunocytological study in the central nervous system. Dev Biol 83:311-327.

Stemple DL, Anderson DJ (1992) Isolation of a stem cell for neurons and glia from the mammalian neural crest. Cell 71:973-985.

Temple S (1989) Division and differentiation of isolated CNS blast cells in microculture. Nature 340:471-473.

Timsit SG, Bally-Cuif L, Colman DR, Zalc B (1992) DM-20 mRNA is expressed during the ennbryonic development of the nervous system of the mouse. J Neurochem 58:1172-1175.

Tohyama T, Lee VMY, Rorke LB, Marvin M, McKay RDG, Trojanowski JQ (1992) Nestin expression in embryonic human neuroepithelium and in human neuroepithelial tumor cells. Lab Invest 66: 303-313.

Tontsch U, Archer DR, Dubois-Dalcq M, Duncan ID (1994) Transplantation of an oligodendrocyte cell line leading to extensive myelination. Proc Natl Acad Sci USA, in press.

Trotter J, Bitter-Suemann D, Schachner M (1989) Differentiationregulated loss of the polysialylated embryonic form of the different polypeptides of the neural cell adhesion molecule by cultured oligodendrocytes and myelin. J Neurosci Res 22:369-383.

Vaysse PJJ, Goldman JE (1990) A clonal analysis of glial lineages in neonatal forebrain development in vitro. Neuron 5:227-235.

Vescovi AL, Reynolds BA, Fraser DD, Weiss S (1993) bFGF regulates 
the proliferative fate of unipotent (neuronal) and bipotent (neuronal/ astroglial) EGF-generated CNS progenitor cells. Neuron 11:951-966.

Warrington AE, Pfeiffer SE (1992) Proliferation and differentiation of $\mathrm{O}^{+}$oligodendrocytes in postnatal rat cerebellum: analysis in unfixed tissue slices using anti-glycolipid antibodies. J Neurosci Res 33:338353.

Wilkin GP, Levi G, Johnstone SR, Riddle PN (1983) Cerebellar astroglial cells in primary culture: expression of differentiated morphological appearances and different ability to take up D- $\left[{ }^{3} \mathrm{H}\right]$ aspartate and $\left.{ }^{3} \mathrm{H}\right]$ GABA. Dev Brain Res 10:265-277.
Williams BP, Read J, Price J (1991) The generation of neurons and oligodendrocytes from a common precursor cell. Neuron 7:685-693.

Zeller NK, Behar TN, Dubois Dalcq ME, Lazzarini RA (1985) The timely expression of myelin basic protein gene in cultured rat brain oligodendrocytes is independent of continuous neuronal influences. J Neurosci 5:2955-2962.

Zimmermann L, Lendhal U, Cunningham M, McKay R, Parr B, Gavin B, Mann J, Vassileva G, McMahon A (1994) Independent regulatory elements in the nestin gene direct transgene expression to neural stem cells or muscle precursors. Neuron 12:11-24. 